\title{
Blackleg in cattle: current understanding and future research needs
}

\author{
Rosangela Estel Ziech ${ }^{*} \odot$ Leticia Trevisan Gressler ${ }^{2} \odot$

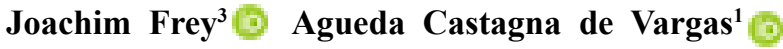

${ }^{1}$ Departamento de Medicina Veterinária Preventiva, Universidade Federal de Santa Maria (UFSM), 97105-900, Santa Maria, RS, Brasil. E-mail: reziech@gmail.com. "Corresponding author.

${ }^{2}$ Instituto Federal Farroupilha (IFFar), Frederico Westphalen, RS, Brasil.

${ }^{3}$ Institute of Veterinary Bacteriology, Vetsuisse Faculty, University of Bern, Bern, Switzerland.

\begin{abstract}
Blackleg is an endogenous acute infection that principally affects cattle, whose etiologic agent is the anaerobic bacterium Clostridium chauvoei. In recent years, the major virulence factors of C. chauvoei have been discovered and described. However, the pathogenesis of blackleg in cattle, and in particular, the movement of the pathogen from the point of entry to the affected tissues is not yet fully elucidated. Disease control is based on appropriate management and vaccination. This review summarizes the latest research findings that contribute toward the understanding of the disease in cattle, provide a foundation to preventive strategies, and identify future research needs. Key words: Clostridium chauvoei, sudden death, myonecrosis.
\end{abstract}

Carbúnculo sintomático: compreensão atual e futuras necessidades de pesquisa

RESUMO: $O$ carbúnculo sintomático é uma infecção endógena, aguda, que acomete principalmente bovinos, cujo agente etiológico é a bactéria anaeróbica Clostridium chauvoei. Recentemente, os principais fatores de virulência do C. chauvoei foram descobertos e descritos. Contudo, a patogênese do carbúnculo sintomático em bovinos, especialmente a circulação do patógeno desde o ponto de entrada até os tecidos acometidos ainda não está completamente elucidada. O controle desta enfermidade é baseado em medidas adequadas de manejo e vacinação. Esta revisão reúne as mais recentes descobertas que contribuíram para o entendimento da doença em bovinos, fornece embasamento para medidas preventivas e aponta futuras necessidades de pesquisa.

Palavras-chave: Clostridium chauvoei, morte súbita, mionecrose.

\section{INTRODUCTION}

Blackleg, also known as black quarter, is a generally fatal form of myonecrosis usually observed in young cattle (USEH et al., 2006b). Clostridium chauvoei, the etiologic agent of blackleg, is a grampositive, motile, histotoxic, and sporulating anaerobic bacterium (QUINN et al., 2011). This infectious disease is acute and globally spread among ruminants, causing significant loss in livestock production (FREY \& FALQUET, 2015). Although blackleg vaccination has been carried out since 1930, sporadic outbreaks are still recorded annually worldwide (USEH et al., 2006b).

In 1782, Chabert differentiated between blackleg and anthrax on the basis of symptomatic and pathological features (KRIEK \& ODENDAAL, 2004). Although blackleg is one of the oldest known diseases affecting cattle, there are important gaps in the understanding of this disease, especially with respect to its pathogenesis. Focusing on the cattle disease, this article aims to offer an overview of the current knowledge about the etiology, virulence factors, epidemiology, pathogenesis, diagnosis, and prevention of blackleg and to identify areas for further research and development.

\section{Epidemiology and clinical and pathological manifestation}

Blackleg is an endemic disease in both developed and developing countries and a well-known cause of financial loss to cattle breeders (USEH et al., 2006b). Most cases of blackleg occur during the warm months, or after soil excavation, or during very high annual rainfall that can expose and activate latent spores. In addition, the disease is enzootic in areas with a history of flooding (USEH et al., 2006a; HUANG et al., 2013). 
The type of soil and water permeability might represent an important indicative factor in surveillance programs, which was once associated with an increased risk of blackleg cases in Zambia (HANG'OMBE et al., 2000) and Austria (WOLF et al., 2017).

Cattle aged between 6 to 24 months, in good health, are mostly affected (UZAL, 2012). The clinical signs of the hyperacute form of this disease are usually not observed because of sudden death. The acute form of the disease is often reported with swelling and crepitus of affected muscles (SINGH et al., 1993).

The most commonly reported findings in classical blackleg are acute neutrophil necrotizing myositis that affects the skeletal muscle, and visceral myonecrosis, which is rarely diagnosed, but can affect the heart, sublingual muscles, and diaphragm (ASSIS et al., 2010; CASAGRANDE et al., 2015). Other unusual findings include fibrinous pleuritis, pericarditis, epicarditis (DALY et al., 2009), and severe acute necrotizing enteritis (HARWOOD et al., 2007) as well as the highly uncommon meningoencephalitis (MALONE et al., 1986; SAC, 2016).

\section{Etiology and virulence factors}

Blackleg is caused by an anaerobic, highly pathogenic, endospore-forming, gram-positive bacterium called $C$. chauvoei, which produces lemonshaped endospores and requires an enriched medium for growth (QUINN et al., 2011). The first draft genome sequence of a virulent $C$. chauvoei strain became available in 2013; it consists of 2.8 million base pairs (bp) (FALQUET et al., 2013). Moreover, it contains a cryptic plasmid, about $5.5 \mathrm{kbps}$ in size (FREY \& FALQUET, 2015). Recently, the full genome sequences of 20 strains of C. chauvoei, isolated from four different continents over a period of 64 years, were determined and analyzed. The results of this study showed that the strains analyzed were highly conserved, which further indicates that the evolution of C. chauvoei has reached a dead end (RYCHENER et al. 2017).

The relative small genome of $C$. chauvoei, compared to other Clostridium species such as $C$. difficile (4.2 million bp) (SEBAIHIA et al., 2006), reflects its adaptation to a restricted host range (bovine, caprine, and ovine), where C. chauvoei is able to replicate and cause disease (FREY \& FALQUET, 2015). However, a comparative analysis of the circular genome sequences of the $C$. chauvoei type strain (ATCC 10092) and the field strain 12S0467 isolated in Germany showed novel variations in the regulatory genes, indicating that $C$. chauvoei has specific control of the regulatory events, unlike the genomes of other Clostridium species (THOMAS et al., 2017).

C. chauvoei has 69 genes dedicated to the mechanisms involved in sporulation and dormancy (FREY \& FALQUET, 2015), which might be considered as virulence factors that enable the pathogen to resist adverse environmental conditions and remain potentially infectious over years (GALPERIN et al., 2012). Recently, it was observed that the genes related to sporulation and germination in C. chauvoei are homologous to those in Clostridia cluster I group, that includes $C$. botulinum, $C$. haemolyticum, C. novyi, C. perfringens, C. tetani, $C$. septicum, and C. chauvoei (THOMAS et al., 2017). Furthermore, C. chauvoei produces several cellular (somatic and flagellar) (CRICHTON et al., 1990) and soluble antigens associated with virulence.

\section{Cellular antigens}

Somatic antigens are associated with the bacterial cell. Such antigens are considered crucial immunogenic components involved in the protection against $C$. chauvoei infection, and therefore, current and old vaccines contained bacterins or were solely composed of bacterins (CHANDLER and GULASEKHARAM, 1974). In this sense, some studies aiming to improve vaccine quality have described important characteristics of somatic antigen expression. The amount of somatic antigens varies with bacterial growth as well as environmental conditions such as $\mathrm{pH}$ and carbohydrate availability, showing increased expression during the stationary phase of growth in axenic culture medium (CORTINAS et al., 1994). However, the expression of these antigens does not seem to vary among strains from different origins (MATTAR et al., 2002), which underlines the very high genetic similarity observed among strains from all over the globe (RYCHNER et al., 2017).

Flagellar antigens have been studied extensively, highlighting flagellin, which is encoded by the $\mathrm{fliC}$ gene. Flagellin has a pathogen-associated molecular pattern (PAMP) that is recognized by tolllike receptor 5 (TLR5) expressed by monocytes and fibroblasts. The receptors at the surface of intestinal epithelial cells bind the conserved regions of flagellin ( $\mathrm{N}$ and $\mathrm{C}$ terminals), resulting in the activation of cytokine secretion (YOON et al., 2012). Flagellin was found to be important for protective immunity by opsonic activity, resulting in the clearance of C. chauvoei by polymorphonuclear leukocytes in mice (TAMURA \& TANAKA, 1984; TAMURA \& TANAKA, 1987). Flagellar expression and motility are reversible in $C$. chauvoei and are associated with complete expression of virulence (TAMURA et al., 
1995). Further studies characterized flagellin and evaluated its protective activity by using a recombinant flagellin protein (KOJIMA et al., 1999; 2000). These authors reported poor protective immunity induced by the recombinant flagellin in mice, suggesting that a conformation-dependent epitope plays an important role in the development of immunity against blackleg. The poor protective activity of the recombinant flagellin protein observed previously (KOJIMA et al., 2000) can be attributed to the fact that these authors did not considered that there are a minimum of two copies of $\mathrm{fliC}$ gene on the chromosome of $C$. chauvoei (SASAKI et al., 2002). RYCHENER et al., (2017) found three copies of the allelic variants $\mathrm{fliC} 1, \mathrm{fliC} 2$, and $f i C 3$ of flagellin in most strains studied, thus showing $91.8 \%$ amino acid identity with each other in a given strain and $82-96 \%$ identity between the paralogues of different strains. THOMAS and collaborators (2017) also revealed the presence of three $\mathrm{fliC}$ genes.

The cell surface-associated antigens of C. chauvoei, other than flagellin, have not yet been explored. USHARANI et al., (2016) identified some important cell surface-associated proteins of $C$. chauvoei, such as enolase, chaperonin, ribosomal protein L10, flavoprotein, and glycosyl hydrolase, which showed protective antigenicity in other bacteria. However, further studies are necessary to evaluate the role of these surface-associated proteins in protection against blackleg.

\section{Soluble antigens and toxins}

The soluble antigens, mainly represented by toxins, are deeply involved in the pathogenesis of blackleg. At present, five $C$. chauvoei toxins are known: the hemolytic leukocidin CctA, oxygen-labile hemolysin D (or hemolysin III), DNase ( $\beta$-toxin), hyaluronidase Nag (previously called $\gamma$-toxin), and neuraminidase/sialidase NanA.

The pore-forming, oxygen-stable leukocidin hemolysin called $C$. chauvoei cytotoxin A (CctA) confers strong hemolytic activity, which is observed as a halo around the colonies on blood agar growth medium (FREY et al., 2012). CctA as a mature protein has a molecular mass of $32.2 \mathrm{kDa}$. It is a major toxin and hemolysin produced by $C$. chauvoei, which is shown to be highly cytotoxic to the bovine epithelial cell line ECaNEp (FREY et al., 2012). In addition, FREY et al., (2012) used the conventional assay for testing the potency of blackleg vaccine, which contains purified recombinant $\operatorname{Cct} A$ as the sole antigen, and protects $80 \%$ guinea pigs from the challenge with virulent $C$. chauvoei. The antibodies directed against CctA play the main role in the protective immunity exerted against blackleg; thus, it is a valuable candidate for blackleg vaccines and for the potency testing of current vaccines.

The previously described oxygen-stable necrotizing hemolysin ( $\alpha$-toxin) (HANG'OMBE et al., 2006) might be CctA, although the reported molecular mass of this $\alpha$-toxin hemolysin is $25 \mathrm{kDa}$, which is significantly lower. Alternatively, this $\alpha$-toxin could represent the putative hemolysin III, also called hemolysin D or $\delta$-toxin (protein \#276) found on the genome of $C$. chauvoei (FREY \& FALQUET, 2015), whose molecular mass is around $25 \mathrm{kDa}$. However, the latter might correspond to a weak hemolysin that is oxygen labile and potentially thiol-activated (GILBERT, 2002). It must be noted that hemolysin III is not specific to C. chauvoei as several pathogenic, commensal, and environmental grampositive bacteria express it or carry genes coding for this class of hemolysin. Although there is no clarity about hemolysin III in C. chauvoei, it is reported to be similar to the $\theta$-toxin produced by $C$. perfringens and the tetanolysin produced by $C$. tetani (HATHEWAY, 1990). Using monospecific antibodies directed against CctA, FREY et al., (2012) fully neutralized all the hemolytic activity expressed by $C$. chauvoei, showing that other than $\operatorname{CctA}$, this pathogen does not produce any entity with measurable hemolytic activity.

DNase ( $\beta$-toxin) is an enzyme of the deoxyribonuclease type; it is a thermostable protein responsible for the nuclear degradation of muscle cells (HATHEWAY, 1990). This toxin actively participates in clostridial myonecrosis (CORTINAS et al., 1999). It was found in $>80 \%$ C. chauvoei strains isolated from cattle (CARLONI et al., 2005), although the strains showed different capacities of toxin production. Full genome analysis of $C$. chauvoei revealed the presence of two genes encoding the large and small subunits of exo-deoxyribonuclease VII that most likely represent the DNase activity of $C$. chauvoei (FALQUET et al., 2013). The genes encoding exo-deoxyribonuclease VII are present and fully conserved in all 20 strains of C. chauvoei (RYCHENER et al., 2017).

Hyaluronidase ( $\gamma$-toxin) is an enzyme inactivated by heat and capable of breaking down hyaluronic acid. It is assumed to be responsible for the destruction of the loose connective tissue that surrounds the muscles, thus favoring the spread of C. chauvoei in the tissues of the infected host (HATHEWAY, 1990). In addition, the end products of hyaluronate degradation are disaccharides, which might be a source of nutrients for the pathogen (HYNES \& WALTON, 2000). The genome of $C$. chauvoei has two different hyaluronidase genes, 
namely, nagH and nagJ. Currently, the functional activity of $n a g H$ has been confirmed (FREY \& WÜTHRICH, unpublished data).

Neuraminidase/sialidase (NanA) was purified and characterized by HEUERMANN et al., (1991). They showed that the enzymatic activity cleaves $\mathrm{N}$-acetylneuraminic acid (sialic acid) in carbohydrate polymers, present in many mammalian cell membranes as well as many microorganisms (USEH et al., 2003). NanA was characterized in detail as an $81-\mathrm{kDa}$ protein that is secreted as a dimer (VILEI et al., 2011). It is encoded by the nanA gene, which is fully conserved across the $C$. chauvoei strains isolated over 60 years from various geographical locations across four different continents (RYCHENER et al., 2017). A recombinant molecule derived from nanA containing the sialic acid-binding domain (CBM40) is able to fully neutralize the sialidase activity of $C$. chauvoei (VILEI et al., 2011). Thus, NanA can also be used as a potential antigen to aid protective immunity.

The findings about the protective immunity exerted by soluble antigens against blackleg leave no doubt about the importance of these antigens in the pathogenesis of this condition. Interestingly, the sialidase nanA, hyaluronidase $n a g H$ and nagI, and leukocidin $c c t A$ genes are well conserved in $C$. chauvoei strains (VILEI et al., 2011; FREY et al., 2012; RYCHENER et al., 2017). Thus, the failures in vaccine development cannot be explained by the variations in the genes encoding major soluble antigens. A schematic illustration of blackleg pathogenesis, along with the major virulence factors, is shown in figure 1 .

\section{Pathogenesis}

Although blackleg is a clinically wellknown disease, there is currently no consensus on the mechanisms underlying the pathogenesis of $C$. chauvoei. C. chauvoei spores are found in cattle gut as well as in pasture soil, which indicates that the infection is acquired by the ingestion of $C$. chauvoei spores. The ingested spores or those produced after germination cycles in the gut are transported from the intestine or lesions in the oral cavity to the muscles and tissues by macrophages across Peyer's patches (JUBB et al., 1991; PIRES et al., 2012; UZAL, 2012). After reaching

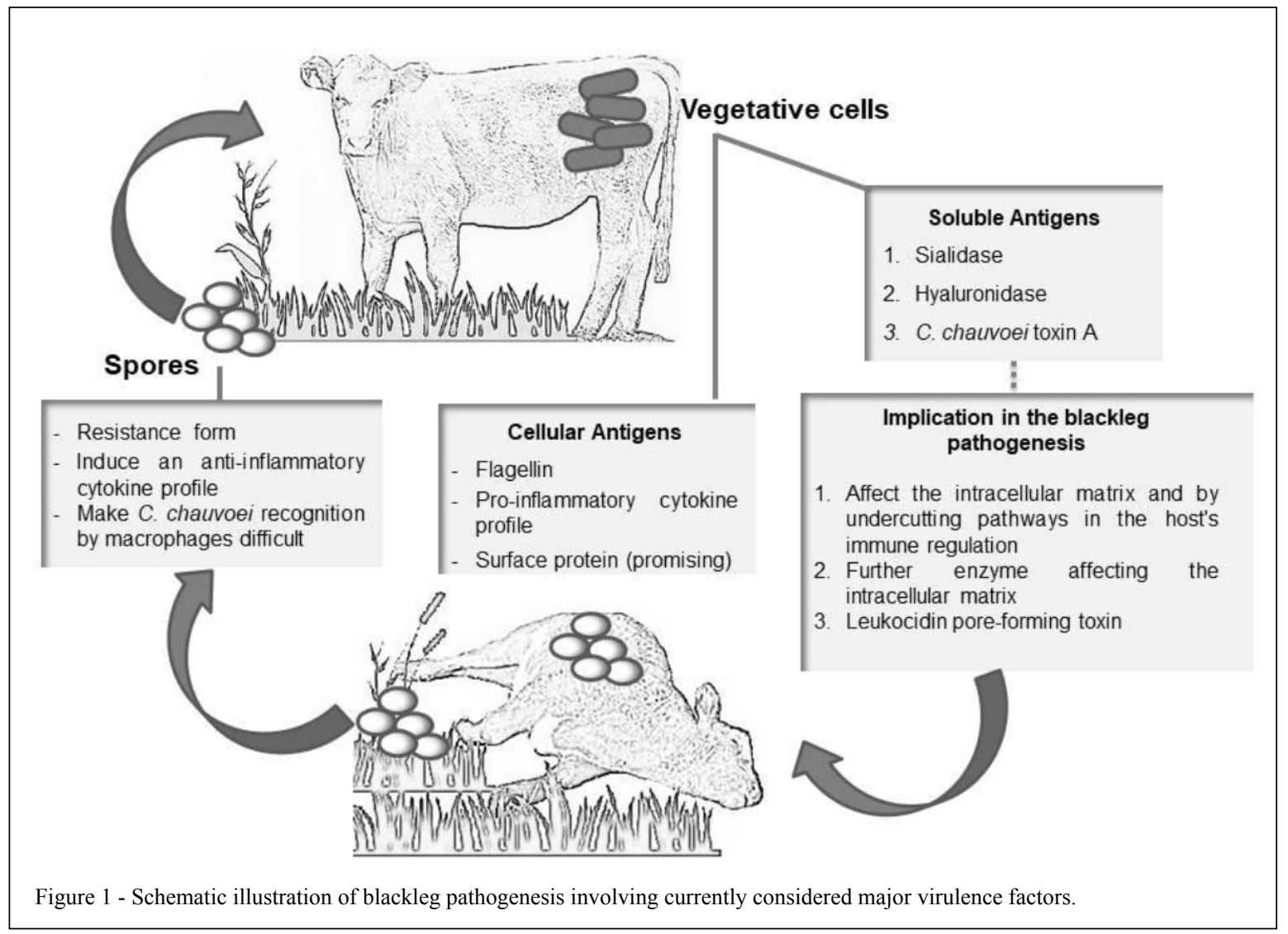

Ciência Rural, v.48, n.5, 2018. 
the tissues, the spores remain dormant until specific conditions are generated, such as anaerobiosis, resulting in their germination, multiplication, and consequently production of exotoxins (UZAL et al., 2012).

After a traumatic injury, the oxygen levels of the muscle tissue reduce, and the lactic acid concentration increases anaerobically during glycolysis (conversion of pyruvate to lactate), leading to the germination of spores, multiplication of bacteria, and consequent toxin production (MINETT, 1948a; UZAL et al., 2003). However, these hypotheses are not enough to explain why only young animals are affected or why the diaphragm or heart is the only affected area at times. In addition, it is not known whether the conditions allow the germination of latent spores in cases where there is no muscular injury, possibly because of the higher concentration of muscle glycogen caused by the high degree of muscle synthesis, which can serve as a substrate for C. chauvoei (VAN VLEET \& VALENTINE, 2007). Latent spores of $C$. chauvoei can be found in healthy cattle carcass, in organs such as the liver and spleen (MINETT, 1948b; KERRY, 1964; SATHISH \& SWAMINATHAN, 2009). In a surveillance study involving two slaughter houses of Sao Paulo, Brazil, C. chauvoei was identified by microbiological culture in $7.5 \%$ of muscle samples and $1.7 \%$ of liver samples (SCHOCKEN-ITURRINO et al., 2000).

A recent study showed that the vegetative and sporulated forms of $C$. chauvoei are able to resist the microbicidal effects of macrophages in murine and bovine monocyte-derived macrophages, supporting the importance of macrophages during the early pathogenesis of blackleg (PIRES et al., 2017). These authors also noted a pro-inflammatory cytokine profile such as IL-12 and IL-23 transcription in bovine macrophages after infection with vegetative C. chauvoei. Conversely, in bovine macrophages infected with the spores of $C$. chauvoei, an antiinflammatory cytokine profile such as induction of IL-10 and TGF-beta transcription was observed (PIRES et al., 2017). The anti-inflammatory profile induced by spores might explain their latency after macrophage internalization. Future research should, thus, investigate the possible role of genetic susceptibility in the occurrence of blackleg. A starting point could be the genetic characterization of the ability of phagocytic cells, especially macrophages, to clear C. chauvoei post internalization.

\section{Diagnosis}

Very few affected animals survive, and death usually occurs within $48 \mathrm{~h}$ of clinical manifestation. Once the animals die on the pasture, postmortem decomposition complicates an accurate diagnosis (DALY et al., 2009). A preliminary diagnosis of blackleg can be undertaken on the live animal on the basis of clinical signs and the presence of typical muscle emphysema. Postmortem findings include dark, discolored, swollen, and rancid muscle upon incision of the affected area. The affected muscle will contain excess fluid and gas bubbles and smell like rancid butter because of bacterial production of butyric acid. Body cavities will also contain excess fluid. Overall, tissue decomposition is rapid, assumingly by the action of potent toxins. In cardiac myositis, fluid accumulation is observed around the heart, with large amounts of fibrin too (SULTANA et al., 2008).

Traditionally, the diagnosis of blackleg is confirmed by microbiological culture and isolation of the causative microorganism. However, this is not always successful because of the difficulties in obtaining, submitting, and processing the samples in the laboratory. FARIAS et al., (2012) proposed the use of direct polymerase chain reaction (PCR) using common filter paper as an alternative to collecting, storing, and shipping material to the laboratory for the diagnosis of blackleg; the sensitivity and specificity of this approach was $100 \%$. In addition, C. chauvoei is sensitive to oxygen, and it tends to be overgrown easily by other microorganisms in the samples (ASSIS et al., 2005).

Routine clinical microbiology laboratory tests might falsely identify C. septicum, instead of C. chauvoei (NAGANO et al., 2008). It is difficult to differentiate between $C$. chauvoei and $C$. septicum because of morphological and biochemical similarities. Based on 16S rDNA sequence analysis, C. chauvoei and C. septicum have been identified as closely related species with a high level of similarity (99.3\%) (KUHNERT et al., 1996). THOMAS et al., (2017) also showed high relatedness (74\%) between $C$. chauvoei and $C$. septicum by phylogenomic analysis. It should be noted that $C$. septicum is a microorganism capable of initiating malignant edema, a highly lethal exogenous infection (ASSIS et al., 2012). In humans, C. septicum is an important cause of death from spontaneous, nontraumatic gas gangrene in both adults and children (ABELLA et al., 2003; SMITH-SLATAS et al., 2006). BARNES et al., (1975) suggested that some of the deaths related to $C$. chauvoei are caused by $C$. septicum or a co-infection with $C$. chauvoei and $C$. septicum.

Further diagnostic methods for the identification and differentiation of $C$. chauvoei and $C$. septicum include immunofluorescence assays (SEISE et al., 2014), immune histochemistry (ASSIS et al., 2005), and MALDI-TOF 
MS technology (GROSSE-HERRENTHEY et al., 2008). Molecular assays such as conventional PCR on the 16S rRNA genes (KUHNERT et al., 1997, 1996; UZAL et al., 2003), 16S and 23S rDNA spacer regions (SASAKI et al., 2001; IDREES et al., 2014) (SASAKI et al., 2001; IDREES et al., 2014), and flagellin genes (KOJIMA et al., 2001; SASAKI et al., 2002) and a multiplex real-time PCR (GAROFOLO et al., 2011; HALM et al., 2010; LANGE et al., 2010) have also been used as diagnostic methods. A recombinant flagellin-based ELISA assay was developed for the detection of $C$. chauvoei and could detect up to $10^{4} \mathrm{CFU} / \mathrm{mL}$ of $C$. chauvoei, in addition to its high specificity (USHARANI et al., 2015).

\section{Prevention and control}

Although published studies about the ability of vaccination to prevent morbidity and mortality by blackleg in cattle are scarce (UZAL, 2012), vaccination is the principal prophylactic measure that can be used to control the disease (CHANDLER \& GULASEKHARAM, 1974). ARAUJO et al., (2010) evaluated the serological response of beef calf tissue subjected to different vaccination regimens. This study showed that booster shots significantly increased the serological response at 30 days post immunization. The serum IgG levels against $C$. chauvoei were significantly higher in calves that were first vaccinated at four months, compared to calves vaccinated at eight months of age. The serological response of calves that were vaccinated twice was found to be satisfactory, independent of the first vaccination being given at four or eight months of age. According to ARAUJO et al., (2010), cattle should be vaccinated at four months of age, followed by a booster dose one month later, and then annually repeated. For disease control, it is important to highlight that the carcasses of animals suffering from blackleg must be burned to restrain the contamination of pastures.

Some authors consider that the use of native strains can improve commercial vaccine preparations, by increasing bovine immune response (ORTIZ-ORTEGA et al., 2012). However, a recent study involving whole genome analysis of 20 strains of $C$. chauvoei isolated across four continents over 64 years (RYCHENER et al., 2017) indicated virtually no genomic variations between the strains used in vaccines and those obtained from outbreaks, suggesting that the reason for vaccine failure could be a factor other than the lack of similarity between the two sets of strains. Given that vaccination is quite common, and so are disease outbreaks, essential questions continue to remain about the causes for vaccine failure. Most likely, practical issues such as management failures, inconsistent vaccination, delayed application of the first dose, incorrect timing of booster doses, and vaccination of dams are the causes for vaccine failure. In addition, cattle breeders tend to stop vaccinating herds when the outbreaks reduce, and as a result, the disease recurs.

Because $C$. chauvoei survives within macrophages, inactivated vaccines might not elicit the best type of immune response (cellular immunity). In Brazil, a live attenuated vaccine was patented by the Institute Oswado Cruz in 1908 (GODOY, 1910). This was the only live vaccine against $C$. chauvoei available in the world. However, since 2014, the production of this vaccine was stopped despite personal observations that this widely used live vaccine promoted adequate protection against blackleg in Brazil.

The potential underestimation of blackleg incidence is a limiting factor for prevention and control measures. Farmers form an important bridge between the cases of blackleg and official surveillance programs. Offering compensation for reporting a case might motivate the farmers to report every case. Additionally, a subsidized vaccination program could help control blackleg occurrence and thus reduce environmental contamination with C. chauvoei spores, especially in high-risk areas. Alternative measures to prevent and control blackleg can focus on specific pasture management practices, like artificial drainage of pastures. In fact, a recent study pointed out that blackleg cases are usually clustered within geographic areas with poor water permeability (WOLF et al., 2017).

\section{CONCLUSION}

Blackleg is an acute and often fatal infection occurring in cattle that continues to remain endemic worldwide despite large vaccination programs. Studies characterizing cellular and soluble antigens are necessary to improve the chances of developing a protective vaccine. We also highlighted that the commercial vaccines are bacterins that are probably ineffective in extending immunity against C. chauvoei spores, sialidase, and CctA.

\section{ACKNOWLEDGEMENTS}

The authors are thankful for the financial support received from the Fundação de Amparo à Pesquisa do Estado do Rio Grande do Sul (FAPERGS), the Conselho Nacional de Desenvolvimento Científico e Tecnológico (CNPq), and the $3 \mathrm{R}$ Foundation (grant $\mathrm{n}^{\circ} 136-13$ to JF). 


\section{DECLARATION OF CONFLICT OF INTEREST}

The authors declared no potential conflicts of interest with respect to the research, authorship, and/or publication of this article.

\section{REFERENCES}

ABELLA, B.S. et al. Atraumatic clostridial myonecrosis: Case report and literature review. Journal of Emergency Medicine, v.24, p.401-405, 2003. Available from: <http://www.jem-journal. com/article/S0736-4679(03)00037-4/abstract>. Accessed: Nov. 10, 2017. doi: 10.1016/S0736-4679(03)00037-4.

ARAUJO, R.F. et al. Vaccination protocol and bacterial strain affect the serological response of beef calves against blackleg. Pesquisa Veterinária Brasileira, v.30, p.554-558, 2010. Available from: $<$ http://www.scielo.br/scielo.php?script=sci_arttext\&pid=S0100736X2010000700008>. Accessed: Jan. 20, 2016. doi: 10.1590/ S0100-736X2010000700008

ASSIS, R.A. et al. Sequencing and phylogenetic analysis of Clostridium septicum alpha toxin gene from Brazilian field and vaccine strains. African Journal of Microbiology Research, v.6, p.1685-1689, 2012. Available from: <http:// www.academicjournals.org/journal/AJMR/article-abstract/ D907AF014102>. Accessed: Nov. 19, 2016. doi: 10.5897/ AJMR11.886.

ASSIS, R.A. et al. Mionecroses clostridiais bovinas. Arquivos do Instituto Biológico, v.77, p.331-334, 2010.

ASSIS, R.A. et al. Immunohistochemical detection of Clostridia species in paraffin-embedded tissues of experimentally inoculated guinea pigs. Pesquisa Veterinária Brasileira, v.25, p.4-8, 2005. Available from: <http://www.scielo.br/scielo.php?pid=S0100736X2005000100002\&script $=$ sci abstract\&tlng $=\mathrm{pt}>$. Accessed: Nov. 10, 2017. doi: 10.1590/S0100-736X2005000100002.

BARNES, D.M. et al. Differential diagnosis of clostridial myonecrosis. The Canadian Veterinary Journal, v.16, p.357359, 1975. Available from: <https://www.ncbi.nlm.nih.gov/pmc/ articles/PMC1697094/>. Accessed: Nov. 19, 2016.

CARLONI, G.H. et al. Detección de la actividad de desoxiribonucleasa (DNasa) en cepas de Clostridium chauvoei. Revista Argentina de Microbiologia, v.37, p.87-88, 2005. Available from: $<$ http://www.scielo.org.ar/scielo.php?script=sci ar ttext\&pid=S0325-75412005000200006 $>$. Accessed: Feb. 04, 2016.

CASAGRANDE, R.A. et al. Histopathological, immunohistochemical and biomolecular diagnosis of myocarditis due to Clostridium chauvoei in a bovine. Ciência Rural, 2015. Available from: $<$ http://www.scielo.br/scielo.php?script=sci artte xt\&pid=S0103-84782015000801472>. Accessed: Nov. 19, 2016. doi: $10.1590 / 0103-8478 \mathrm{cr} 20141447$.

CHANDLER,H.Metal. Theprotectiveantigen ofahighlyimmunogenic strain of Clostridium chauvoei including an evaluation of its flagella as a protective antigen. Journal of General Microbiology, v.84, p.128-134, 1974. Available from: <http://mic.microbiologyresearch. org/content/journal/micro/10.1099/00221287-84-1-128>. Accessed: Nov. 19, 2016. doi: 10.1099/00221287-84-1-128.

CORTINAS, T.I. et al. Influence of culture conditions on growth and protective antigenicity of Clostridium chauvoei. Journal of
Applied Microbiology, v.77, 1994. Available from: <https://www. ncbi.nlm.nih.gov/pubmed/7989266>. Accessed: Nov. 10, 2017.

CORTINAS, T.I. et al. Alpha and beta toxin activities in local strains of Clostridium chauvoei. Anaerobe, v.5, p.297-299, 1999.

CRICHTON, R. et al. The development of an enzyme-linked immunosorbent assay for measuring the potency of vaccines containing Clostridium chauvoei antigens. Biologicals, v.18, p.4954, 1990. Available from: <http://www.sciencedirect.com/science/ article/pii/104510569090070G $>$. Accessed: Nov. 10, 2017. doi: 10.1016/1045-1056(90)90070-G.

DALY, R.F. et al. Blackleg (Clostridium chauvoei infection) in beef calves: a review and presentation of two cases with uncommon pathologic presentations. Bovine Practitioner, v.43, p.153-158, 2009.

FALQUET, L. et al. Draft genome sequence of the virulent Clostridium chauvoei reference strain JF4335. Genome Announcements, v.1, p.1, 2013. Available from: <https://www. ncbi.nlm.nih.gov/pubmed/23950118>. Accessed: Nov. 10, 2017. doi: 10.1093/nar/gkq.

FARIAS, L.D.A. et al. Molecular identification of Clostridium chauvoei from common filter paper. Acta Scientiae Veterinariae, v.40, p.1-5, 2012. Available from: <http://www.ufrgs.br/ actavet/40-4/PUB\%201075.pdf>. Accessed: Nov. 19, 2016.

FREY, J. et al. Cytotoxin CctA, a major virulence factor of Clostridium chauvoei conferring protective immunity against myonecrosis. Vaccine, v.30, p.5500-5505, 2012. Available from: $<$ https://www.ncbi.nlm.nih.gov/pubmed/22749595>. Accessed: Nov. 19, 2016. doi: 10.1016/j.vaccine.2012.06.050.

FREY, J. et al. Patho-genetics of Clostridium chauvoei. Research in Microbiology, v.166, p.384-392, 2015. Available from: $<$ https://www.ncbi.nlm.nih.gov/pubmed/25445013>. Accessed: Nov. 19, 2016. doi: 10.1016/j.resmic.2014.10.013.

GALPERIN, M.Y. et al. Genomic determinants of sporulation in Bacilli and Clostridia: towards the minimal set of sporulationspecific genes. Environmental Microbiology, v.14, p.2870 2890, 2012. Available from: <https://www.ncbi.nlm.nih.gov/ pubmed/22882546>. Accessed: Nov. 10, 2017. doi: 10.1111/j.14622920.2012.02841.x

GAROFOLO, G. et al. Development of a real time PCR taqman assay based on the TPI gene for simultaneous identification of Clostridium chauvoei and Clostridium septicum. Journal of Microbiological Methods, v.84, p.307-311, 2011. Available from: $<$ https://www.ncbi.nlm.nih.gov/pubmed/21182874>. Accessed: Nov. 10, 2017. doi: 10.1016/j.mimet.2010.12.017.

GILBERT, R.J.C. Pore-forming toxins. Cellular and Molecular Life Sciences, v.59, p.832-844, 2002. Available from: $<$ https://www.ncbi. nlm.nih.gov/pubmed/12088283>. Accessed: Nov. 19, 2016.

GODOY, A. Nova vacina contra o carbúnculo sintomático. Memórias do Instituto Oswaldo Cruz, v.2, p.11-21, 1910. Available from: <http://www.scielo.br/scielo.php?script=sci_artte xt\&pid=S0074-02761910000100002>. Accessed: Nov. 19, 2016.

GROSSE-HERRENTHEY, A. et al. Challenging the problem of clostridial identification with matrix-assisted laser desorption and ionization-time-of-flight mass spectrometry (MALDI-TOF MS). Anaerobe, v.14, p.242-249, 2008. Available from: $<$ https://www. 
ncbi.nlm.nih.gov/pubmed/18621134>. Accessed: Nov. 19, 2016. doi: 10.1016/j.anaerobe.2008.06.002.

HALM, A. et al. Novel real-time PCR assay for simultaneous detection and differentiation of Clostridium chauvoei and Clostridium septicum in clostridial myonecrosis. Journal of Clinical Microbiology, v.48, p.1093-1098, 2010. Available from: $<$ http://jcm.asm.org/content/48/4/1093.full >. Accessed: Nov. 19, 2016. doi: 10.1128/JCM.01975-09.

HANG'OMBE, B.M. et al. Purification and sensitivity of Clostridium chauvoei hemolysin to various erythrocytes. Comparative Immunology, Microbiology \& Infectious Diseases. v.29, p.263-268, 2006. Available from: <https://www. ncbi.nlm.nih.gov/pubmed/16914203>. Accessed: Nov. 19, 2016. doi: 10.1016/j.cimid.2006.06.002.

Hang'ombe, B.M., Kohda, T., Mukamoto, M., Kozaki, S., 2006. Purification and sensitivity of Clostridium chauvoei hemolysin to various erythrocytes. Comp. Immunol. Microbiol. Infect. Dis. 29, 263-8. doi:10.1016/j.cimid.2006.06.002.

HARWOOD, D.G. et al. Outbreak of intestinal and lingual Clostridium chauvoei infection in two-year-old Friesian heifers. Veterinary Record, v.161, p.307-308, 2007. Available from: $<$ https://www.ncbi.nlm.nih.gov/pubmed/17766810>. Accessed: Nov. 19, 2016.

HATHEWAY, C.L. Toxigenic clostridia. Clinical Microbiology Reviews, v.3, p.66-98, 1990. Available from: <http://cmr.asm.org/content/3/1/66. short>. Accessed: Nov. 19, 2016. doi: 10.1128/CMR.3.1.66.

HEUERMANN, D. Purification and characterization of a sialidase from Clostridium chauvoei NC08596. Glycoconjugate Journal, v.8, p.95-101, 1991. Available from: <http://www.ncbi.nlm.nih. gov/pubmed/1823619>. Accessed: Nov. 19, 2016.

HUANG, S.W. et al. The utilization of a commercial soil nucleic acid extraction kit and pcr for the detection of Clostridium tetani and Clostridium chauvoei on farms after flooding in Taiwan. The Journal of Veterinary Medical Science, v.75, p.489-495, 2013. Available from: $<$ https://www.ncbi.nlm.nih.gov/pubmed/23208321>. Accessed: Nov. 19, 2016. doi:10.1292/jvms.12-0271

HYNES, W.L.; WALTON, S.L. Hyaluronidases of Grampositive bacteria. FEMS Microbiology Letters, v.183, p.201207, 2000. Available from: <https://www.ncbi.nlm.nih.gov/ pubmed/10675584>. Accessed: Nov. 19, 2016. doi: 10.1016/ S0378-1097(99)00669-2.

IDREES, A. et al. Isolation and molecular detection of Clostridium chauvoei alpha toxin gene from clinical cases of black quarter in cattle. Journal of Animal and Plant Sciences, v.24, p.755-759, 2014.

JUBB, K.V.F. et al. Pathology of Domestic Animals, 4th ed. San Diego, 1991.

KERRY, J.B. A note on the occurrence of Clostridium chauvoei in the spleen and livers of normal cattle. Veterinary Record, v.76, p.396-397, 1964.

KOJIMA, A. et al. Characterization of flagellin from Clostridium chauvoei. Veterinary Microbiology, v.67, p.231237, 1999. Available from: <https://www.ncbi.nlm.nih.gov/ pubmed/10418877>. Accessed: Jan. 26, 2016. doi: 10.1016/ S0378-1135(99)00038-3.
KOJIMA, A. et al. Cloning and expression of a gene encoding the flagellin of Clostridium chauvoei. Veterinary Microbiology, v.76, p.359-372, 2000. Available from: <https://www.ncbi.nlm.nih.gov/ pubmed/11000532>. Accessed: Jan. 26, 2016. doi: 10.1016/S03781135(00)00256-X

KOJIMA, A. et al. Rapid detection and identification of Clostridium chauvoei by PCR based on flagellin gene sequence. Veterinary Microbiology, v.78, p.363-371 , 2001. Available from: $<$ https://www. ncbi.nlm.nih.gov/pubmed/11182502>. Accessed: Jan. 26, 2016.

KRIEK, N.P.J. et al. Clostridium chauvoei infections. In: COETZER, R., TUSTIN, R.C. Infectious diseases of livestock. Third edition. Oxford Press, p.1856-1862, 2004.

KUHNERT, P. et al. Phylogenetic positions of Clostridium chauvoei and Clostridium septicum based on 16S rRNA gene sequences. International Journal of Systematic and Evolutionary Microbiology, v.46, p.1174-1176, 1996. Available from: $<$ https:// www.ncbi.nlm.nih.gov/pubmed/8863454>. Accessed: Jan. 26, 2016. doi: 10.1099/00207713-46-4-1174.

KUHNERT, P. et al. Identification of Clostridium chauvoei in cultures and clinical material from blackleg using PCR. Veterinary Microbiology, v.57, p.291-298, 1997. Available from: <https:// www.ncbi.nlm.nih.gov/pubmed/9355263>. Accessed: Jan. 26, 2016. doi: 10.1016/S0378-1135(97)00129-6.

LANGE, M. et al. Development and validation of a multiplex real-time PCR for detection of Clostridium chauvoei and Clostridium septicum. Molecular and Cellular Probes, v.24, p.204-210, 2010. Available from: <https://www.ncbi.nlm.nih. gov/pubmed/20362050>. Accessed: Jan. 26, 2016. doi: 10.1016/j. mcp.2010.03.003.

MALONE, F.E. et al. Pathological changes in the pericardium and meninges of cattle associated with Clostridium chauvoei. Veterinary Record, v.118, p.151-152, 1986. Available from: $<$ https://www.ncbi.nlm.nih.gov/pubmed/3952970>. Accessed: Jan. 26, 2016

MATTAR, M. A. et al. Immunogenic protein variations of Clostridium chauvoei cellular antigens associated with the culture growth phase. FEMS Immunology and Medical Microbiology, v.33, p.9-14, 2002. Available from: <https://www.ncbi.nlm.nih. gov/pubmed/11985962>. Accessed: Jan. 26, 2016. doi: 10.1016/ S0928-8244(01)00302-9.

MINETT, F.C. Pathogenesis of black quarter; tissue damage and spore latency. The Journal of Comparative Pathology and Therapeutics, v.58, p.201-209, 1948a.

MINETT, F.C. Pathogenesis of black quarter; influence of nutrition and of muscular exercise. The Journal of Comparative Pathology and Therapeutics, v.58, p.245-258 1948b.

NAGANO, N. et al. Human fulminant gas gangrene caused by Clostridium chauvoei. Journal of Clinical Microbiology, v.46, p.1545-1547, 2008. Available from: <https://www.ncbi.nlm.nih. gov/pmc/articles/PMC2292918/>. Accessed: Jan. 26, 2016. doi: 10.1128/JCM.01895-07.

ORTIZ-ORTEGA, D. et al. Isolation and typing of Clostridium spp. 16S rRNA from soil samples obtained in areas with sudden mortality history in Colombia. Global Advanced Research Journal of Microbiology, v.1, p.33-40, 2012. 
PIRES, P.S. et al. Comparative analysis of lesions caused by histotoxic clostridia in experimentally induced myonecrosis. Semina: Ciências Agrárias, v.33, p.2337-2345, 2012. Available from: <http://www. uel.br/revistas/uel/index.php/semagrarias/article/view/10374>. Accessed: Jan. 26, 2016. doi: 10.5433/1679-0359.2012v33n6p2337.

PIRES, P.S. et al. Intracellular survival of Clostridium chauvoei in bovine macrophages. Veterinary Microbiology, v.199, p.1-7, 2017. Available from: <https:/www.ncbi.nlm.nih.gov/ pubmed/28110774>. Accessed: Jan. 26, 2018. doi: 10.1016/j. vetmic.2016.11.027.

QUINN, P.J. et al. Veterinary microbiology and microbial disease, Second. ed. Ames, Iowa, USA, 2011.

RYCHENER, L. et al. Clostridium chauvoei, an evolutionary dead-end pathogen. Frontiers in Microbiology, v.8, p.1-13, 2017. Available from: <https://www.ncbi.nlm.nih.gov/pubmed/28649238>. Accessed: Jan. 26, 2018. doi: 10.3389/fmicb.2017.01054.

SAC C VS, V.S. Clostridium chauvoei-associated meningoencephalitis in a calf. Veterinary Record, v.178, p.63-66, 2016. Available from: <https:/www.ncbi.nlm.nih.gov/ pubmed/26769810>. Accessed: Jan. 11, 2017.

SASAKI, Y. et al. Amplification of the 16S-23S rDNA spacer region for rapid detection of Clostridium chauvoei and Clostridium septicum. Research in Veterinary Science, v.71, p.227-229, 2001. Available from: <https://www.ncbi.nlm.nih. gov/pubmed/11900959>. Accessed: Jan. 26, 2016. doi: 10.1053/ rvsc.2001.0495.

SASAKI, Y. et al. Phylogenetic analysis and PCR detection of Clostridium chauvoei, Clostridium haemolyticum, Clostridium novyi types A and B , and Clostridium septicum based on the flagellin gene. Veterinary Microbiology, v.86, p.257-267, 2002. Available from: $<$ https://www.ncbi.nlm.nih.gov/pubmed/11900959>. Accessed: Jan. 26, 2016.

SATHISH, S. et al. Genetic diversity among toxigenic clostridia isolated from soil, water, meat and associated polluted sites in South India. Indian Journal of Medical Microbiology, v.27, p.311-320, 2009. Available from: <http://www.ncbi.nlm.nih.gov/ pubmed/19736399>. Accessed: Jan. 26, 2016. doi: 10.4103/02550857.55443 .

SCHOCKEN-ITURRINO, R.P. et al. Presence of viable spores of bacteria of the genus Clostridium in muscle and liver of bovine slaughtered for consumption. ARS Veterinária, v.16, p.109-111, 2000. Available from: <https://www.cabdirect.org/cabdirect/ abstract/20013110209>. Accessed: Jan. 26, 2016.

SEBAIHIA, M. The multidrug-resistant human pathogen Clostridium difficile has a highly mobile, mosaic genome. Nature Genetics, v.38, p.779-786, 2006. Available from: <https://www. ncbi.nlm.nih.gov/pubmed/16804543>. Accessed: Jan. 11, 2016. doi: $10.1038 /$ ng 1830 .

SEISE, B. et al. Clostridium spp. discrimination with a simple bead-based fluorescence assay. Analytical Methods, v.6, p. 29432949, 2014. doi: 10.1039/c3ay41888j.

SINGH, K.P. Haematological and biochemical alterations in hill bulls infected with Clostridium chauvoei. Acta Veterinaria Brno, v.62, p.89-94, 1993. Available from: <https://actavet.vfu. cz/62/1/0089/>. Accessed: Jan. 11, 2016.
SMITH-SLATAS, C.L. Clostridium septicum infections in children: a case report and review of the literature. Pediatrics, v.117, p.796-805, 2006. Available from: <https:/www.ncbi. nlm.nih.gov/pubmed/16567392>. Accessed: Jan. 11, 2016. doi: 10.1542/peds.2005-1074.

SULTANA, M. Black quarter (BQ) disease in cattle and diagnosis of BQ septicaemia based on gross lesions and microscopic examination. Bangladesh Journal of Microbiology, v.25, p.1316, 2008. Available from: <http://www.banglajol.info/index.php/ BJM/article/view/4848>. Accessed: Jan. 11, 2016.

TAMURA, Y. et al. Effect of antiflagellar serum in the protection of mice against Clostridium chauvoei. Infection and Immunity, v.43, p.612-616, 1984. Available from: <https://www.ncbi.nlm. nih.gov/pubmed/6420346>. Accessed: Jan. 11, 2016.

TAMURA, Y. et al. Opsonic activity of anti-flagellar serum against Clostridium chauvoei by mouse polymorphonuclear leucocytes. Veterinary Microbiology, v.14, p.81-86, 1987. Available from: $<$ https:// www.ncbi.nlm.nih.gov/pubmed/2442881>. Accessed: Jan. 11, 2017.

TAMURA, Y. et al. Reversible expression of motility and flagella in Clostridium chauvoei and their relationship to virulence. Microbiology, v.141, p.605-610, 1995. Available from: <https:// www.ncbi.nlm.nih.gov/pubmed/7711898>. Accessed: Jan. 11, 2016. doi: 10.1099/13500872-141-3-605.

THOMAS, P. et al. First report of two complete Clostridium chauvoei genome sequences and detailed in silico genome analysis. Infection, Genetics and Evolution, v.54, p.287298, 2017. Available from: <https://www.ncbi.nlm.nih.gov/ pubmed/28720440>. Accessed: Jan. 11, 2018. doi: 10.1016/j. meegid.2017.07.018.

USEH, N.M. et al. Pathogenesis and pathology of blackleg in ruminants: the role of toxins and neuraminidase. A short review. The Veterinary Quarterly, v.25, p.155-159, 2003. Available from: $<$ https://www.ncbi.nlm.nih.gov/pubmed/14714738>. Accessed: Jan. 11, 2017. doi: 10.1080/01652176.2003.9695158.

USEH, N.M. et al. Relationship between outbreaks of blackleg in cattle and annual rainfall in Zaria, Nigeria. The Veterinary Record, v.158, p.100-101, 2006a. Available from: <https://www. ncbi.nlm.nih.gov/pubmed/16428667>. Accessed: Jan. 11, 2017. doi: $10.1136 /$ vr.158.3.100.

USEH, N.M. et al. Blackleg in ruminants. CAB Reviews: Perspectives in Agriculture, Veterinary Science, Nutrition and Natural Resources, v.1, p.1-8, 2006b. doi: 10.1079/ PAVSNNR20061040.

USHARANI, J. et al. Development of a recombinant flagellin based ELISA for the detection of Clostridium chauvoei. Anaerobe, v.33, p.48-54, 2015. Available from: <http://linkinghub.elsevier.com/ retrieve/pii/S1075996415000220>. Accessed: Jan. 11, 2017. doi: 10.1016/j.anaerobe.2015.02.001.

USHARANI, J. et al. Proteomic analysis and identification of cell surface associated proteins of Clostridium chauvoei. Anaerobe, v.39, p.77-83, 2016. Available from: <http://linkinghub.elsevier. com/retrieve/pii/S107599641630018X>. Accessed: Jan. 11, 2017. doi: 10.1016/j.anaerobe.2016.03.004.

UZAL, F.A. et al. PCR detection of Clostridium chauvoei in pure cultures and in formalin-fixed, paraffin-embedded tissues. 
Veterinary Microbiology, v.91, p.239-248, 2003. Available from: $<$ https://www.ncbi.nlm.nih.gov/pubmed/12458172>. Accessed: Jan. 11, 2017. doi: 10.1016/S0378-1135(02)00291-2.

UZAL, F. A. Evidence-based medicine concerning efficacy of vaccination against Clostridium chauvoei infection in cattle. Veterinary Clinics of North America - Food Animal Practice, v.28, p.71-77, 2012. Available from: <http://www.ncbi.nlm.nih.gov/pubmed/22374118>. Accessed: Jan. 11, 2017. doi: 10.1016/j.cvfa.2011.12.006.

VAN VLEET, J.F. et al. Muscle and tendon. In: MAXIE, M.G. (Ed.) JUBB, PALMER'S. Pathology of domestic animals. 5.ed. Toronto: Elsevier Saunders, 2007. p.185-279.

VILEI, E.M. et al. Genetic and functional characterization of the NanA sialidase from Clostridium chauvoei. Veterinary Research, v.42, p.2-9, 2011. Available from: <https://www.ncbi.nlm.nih. gov/pmc/articles/PMC3031224/>. Accessed: Jan. 11, 2017. doi: $10.1186 / 1297-9716-42-2$.

WOLF, R. et al. Spatial-temporal cluster analysis of fatal Clostridium chauvoei cases among cattle in Styria, Austria between 1986 and 2013. Preventive Veterinary Medicine, V.138, p.134-138, 2017. Available from: <https://www.ncbi.nlm.nih. gov/pubmed/28237228>. Accessed: Jan. 11, 2017. doi: 10.1016/j. prevetmed.2017.01.019.

YOON, S. et al. Structural basis of TLR5-flagellin recognition and signaling. Science, v.335, p.859-864, 2012. Available from: <http://www.sciencemag.org/cgi/ doi/10.1126/science. $1215584>$. Accessed: Jan. 11, 2017. doi: $10.1126 /$ science. 1215584 . 